\title{
Comparative Assessment of Drug Interactions among Public and Private Sector Hospitals
}

\author{
HAMMAD AHMED BUTT ${ }^{1}$, MUHAMMAD ZEESHAN ANWAR ${ }^{2}$, AKRAM SHAHZAD ${ }^{3}$, AMMARA KHAN ${ }^{4}$, HINA ASLAM ${ }^{5}$, \\ ANUM ASHRAF ${ }^{6}$, TALHA LAIQUE ${ }^{*}$ \\ ${ }^{1}$ Department of Pharmacology, CMH Kharian Medical College, Kharian-Pakistan \\ ${ }^{2}$ Department of Biochemistry, CMH Kharian Medical College, Kharian-Pakistan \\ ${ }^{3}$ Department of Anesthesiology, THQ Hospital Kunjah, Gujrat.-Pakistan \\ ${ }^{4}$ Department of Pharmacology, Nawaz Sharif Medical College, Gujrat-Pakistan \\ ${ }^{5}$ Department of Pharmacology, King Edward Medical University, Lahore-Pakistan \\ ${ }^{6}$ Department of Pharmacology, Sahiwal Medical College, Sahiwal-Pakistan \\ ${ }^{7}$ Department of Pharmacology, Allama lqbal Medical College, Lahore-Pakistan \\ Correspondence to Dr. Talha Laique, Email: talhalaique51@gmail.com Tel:+92-331-0346682
}

\begin{abstract}
Background: Drug-drug interactions (DDIs), being one of the most preventable drug related hazards having serious life threatening adverse consequences or at least results in therapeutic failure.

Aim: To confirm the drug-drug interactions among medical patients at private and public sector hospitals of Jhelum and Kharian.

Study design: Comparative study.

Methodology: The collected data was analyzed for drug interactions. Patients who were being prescribed less than two drugs along with topical drugs (ointments, creams, ear drops and eye drops) were excluded. Information on prescriptions was retrieved from the hospital prescription. SPSS for windows version 20.0 was used to analyze the data. Results were presented as frequency and percentage.

Results: The results showed that the public sector showed 1640 drug interactions, that is $75 \%$; on the other hand, the private sector showed 260 drug interactions, that is $41 \%$.

Conclusions: We concluded that frequency of drug interactions were more in public sector hospitals. Hence, a possible reason for such a result could be the greater patient load on public sector hospitals and less number of appointed doctors in such facilities.
\end{abstract}

Keywords: Adverse Drug Interaction, Drug-Related Problems and Drug-Drug Interaction.

\section{INTRODUCTION}

Drug-drug interactions (DDIs), being one of the most preventable drug related hazards having serious life threatening adverse consequences or at least results in therapeutic failure. ${ }^{1,2}$ The accompanying ADRs may cause severe morbidity or even mortality. ADRs result in 5\% admissions in healthcare settings, of which 0.25 to $25 \%$ are due to DDIs. ${ }^{3-6}$ Detection and proper prevention of DDIs result in avoiding the connected undesirable situations. ${ }^{7}$

DDIs are very widespread in hospital admitted patients. ${ }^{7-9}$ According to various studies conducted in certain wards of a healthcare setting, showed the data regarding reasons for hospitalization, class of drugs and patient populations. ${ }^{10-}$ 14 Studies regarding the DDIs occurrence in OPDs of Pakistan's hospitals are very inadequate and rare. A few studies in developed countries showed $28-83 \%$ prevalence of DDIs in OPDs ${ }^{13-18}$. Factors affecting such findings include work settings, plans, DDls screening tool, and drug prescribing pattern.

Healthcare providers in undeveloped and developed countries, including Pakistan, face various challenges i.e., overburdened patients in hospitals, with multiple diseased states, accompanied by unauthentic previous medication histories $^{19,20}$. In addition, there are no such methods available/adopted to determine the patients' drug adherences, therapeutic outcome levels and ADR reporting

Received on 17-12-2020

Accepted on 13-04-2021 and highlighting systems. ${ }^{19,20}$ Overall, due to these miserable circumstances, it is inevitable to perform studies on DDls occur in OPDs inside Pakistan. The aim of the study was to determine the prevalence of possible DDls that are preventable by proper analyzing the prescriptions of the patients that visit OPDs. Also to evaluate the degree and intensity of the DDIs and to discover the widespread clinically significant interactions.

As per 2016 statistics, Pakistan has got an excess of 1200 public hospitals and 700 private hospitals. Public health facilities in Pakistan provide the bulk of healthcare. ${ }^{21}$ Over the years our population has increased exponentially and such rise is led with a greater burden on the public health sector. Public care institutes are usually the only major healthcare facility in most of the far flung districts or cities. Public sector charges minimal fees and remains affordable to all the population.

The private sector plays a vital role in the delivery of healthcare services in Pakistan as they are well-equipped with modern gadgets. Hence, private healthcare facilities are in greater demand than government sector. ${ }^{21} \mathrm{~A}$ plethora of conditions haunting the public and private sector hospitals can also lead to an increase in drug-drug interactions, an easily preventable cause of patient distress.

The objective of the study was to confirm the drugdrug interactions among medical patients at private and public sector hospitals of Jhelum and Kharian. 


\section{METHODOLOGY}

The collected data was analyzed for drug interactions. Patients who were being prescribed less than two drugs along with topical drugs (ointments, creams, ear drops and eye drops) were excluded. Possible DDIs were analyzed by using drug-reax that unveils information about adverse drug reactions resulting from a DDI, the onset as well as the severity of a potential DDI. It provided information on potential clinical consequences (ADRs). Present study was conducted following approval from ethical review board.

Statistical Analysis: SPSS for windows version 20.0 was used to analyze the data. Results were presented as frequency and percentage.

\section{RESULTS}

A total of 2840 prescriptions revealed a total of 1900 interactions (67\%). Public hospitals had a greater number of interactions in their prescriptions. Out of 2200, 1640 $(75 \%)$ interactions were from public sector hospitals. Among the private hospitals from the two cities, a total of 260 interactions were ascertained from 640 prescriptions $(41 \%)$ as shown in Figure 1.

Figure-1: Overall percentage of drug interactions in hospitals

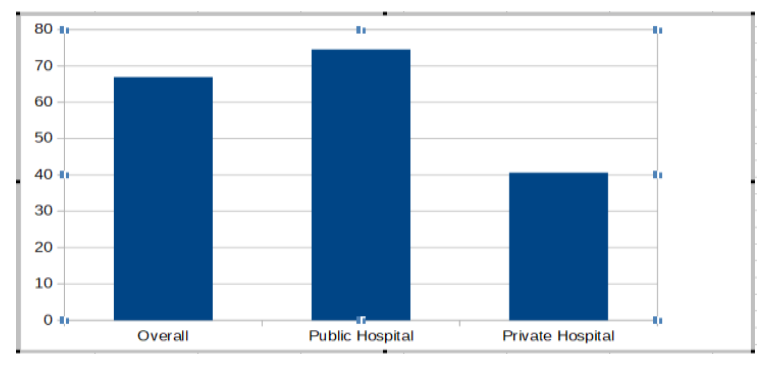

Table-1: Drug interactions at public hospitals of jhelum

\begin{tabular}{l} 
Table-1: Drug interactions at public hospitals of jhelum \\
\begin{tabular}{|l|l|l|}
\hline Drug interaction & Effect & $\begin{array}{l}\text { No of } \\
\text { interactions\% }\end{array}$ \\
\hline $\begin{array}{l}\text { Ibuprofen + } \\
\text { Levofloxacin }\end{array}$ & $\begin{array}{l}\text { Central nervous } \\
\text { system toxicity }\end{array}$ & $220(16.2)$ \\
\hline $\begin{array}{l}\text { Ciprofloxacin }+ \\
\text { Diclofenac }\end{array}$ & $\begin{array}{l}\text { Central nervous } \\
\text { system toxicity }\end{array}$ & $128(9.4)$ \\
\hline Aspirin + Atenolol & $\begin{array}{l}\text { Attenuate the } \\
\text { antihypertensive } \\
\text { effects }\end{array}$ & $96(7.0)$ \\
\hline $\begin{array}{l}\text { Diclofenac + } \\
\text { Levofloxacin }\end{array}$ & $\begin{array}{l}\text { Central nervous } \\
\text { system toxicity }\end{array}$ & $78(5.7)$ \\
\hline $\begin{array}{l}\text { Aspirin + Clopidogrel } \\
\text { Potentiate the } \\
\text { inhibition of platelet } \\
\text { aggregation }\end{array}$ & $42(3.0)$ \\
\hline $\begin{array}{l}\text { Ciprofloxacin } \\
+ \text { Metronidazole }\end{array}$ & $\begin{array}{l}\text { Prolong the QT } \\
\text { interval }\end{array}$ & $36(2.6)$ \\
\hline $\begin{array}{l}\text { Amlodipine }+ \\
\text { Diclofenac }\end{array}$ & $\begin{array}{l}\text { Attenuate the } \\
\text { antihypertensive } \\
\text { effects }\end{array}$ & $36(2.6)$ \\
\hline $\begin{array}{l}\text { Levofloxacin }+ \\
\text { Prednisolone }\end{array}$ & $\begin{array}{l}\text { risk of tendinitis and } \\
\text { tendon rupture }\end{array}$ & $34(2.5)$ \\
\hline $\begin{array}{l}\text { Atorvastatin }+ \\
\text { Clopidogrel }\end{array}$ & $\begin{array}{l}\text { Reduce antiplatelet } \\
\text { effect }\end{array}$ & $32(2.3)$ \\
\hline Aspirin + Glimepiride & $\begin{array}{l}\text { Increase risk of } \\
\text { hypoglycemia }\end{array}$ & $32(2.3)$ \\
\hline
\end{tabular} \\
\hline
\end{tabular}

A high percentage of interactions were found in a public sector Kharian hospital that is $93 \%, 780$ out of 840 prescriptions. Drug interactions from public sector hospitals at Jhelum were shown in Table-1.

Table-2: Drug Interactions At Public Hospital Of Kharian
\begin{tabular}{|l|l|l|}
\hline Drug interaction & Effect & $\begin{array}{l}\text { Number of } \\
\text { interactions\% }\end{array}$ \\
\hline Aspirin + Clopidogrel & $\begin{array}{l}\text { Potentiate the inhibition } \\
\text { of platelet aggregation }\end{array}$ & $244(29)$ \\
\hline Aspirin + Bisoprolol & $\begin{array}{l}\text { Attenuate the } \\
\text { antihypertensive effects }\end{array}$ & $112(13.3)$ \\
\hline Aspirin + Ramipril & $\begin{array}{l}\text { Attenuate the } \\
\text { antihypertensive effects }\end{array}$ & $74(8.8)$ \\
\hline Aspirin + Nitroglycerin & $\begin{array}{l}\text { Enhance the } \\
\text { antihypertensive effect }\end{array}$ & $54(6.42)$ \\
\hline $\begin{array}{l}\text { Hydrochlorothiazide + } \\
\text { Ramipril }\end{array}$ & $\begin{array}{l}\text { Enhance the } \\
\text { antihypertensive effect }\end{array}$ & $42(5.0)$ \\
\hline Aspirin + Furosemide & $\begin{array}{l}\text { Blunt the diuretic and } \\
\text { natriuretic response }\end{array}$ & $34(4.0)$ \\
\hline Aspirin + Lisinopril & $\begin{array}{l}\text { Attenuate the } \\
\text { antihypertensive effects }\end{array}$ & $32(3.8)$ \\
\hline Atorvastatin + Clopidogrel & $\begin{array}{l}\text { Reduce antiplatelet } \\
\text { effect }\end{array}$ & $30(3.6)$ \\
\hline Glimepiride + Levofloxacin & $\begin{array}{l}\text { Hypoglycemia or } \\
\text { hyperglycemia }\end{array}$ & $28(3.3)$ \\
\hline Aspirin + Bisoprolol & $\begin{array}{l}\text { Attenuate the } \\
\text { antihypertensive effects }\end{array}$ & $26(3.1)$ \\
\hline
\end{tabular}

Table-3: Drug Interactions At Private Hospitals Of Jhelum

\begin{tabular}{|l|l|l|}
\hline Drug interaction & Effect & $\begin{array}{l}\text { Number of } \\
\text { interactions\% }\end{array}$ \\
\hline SSRIs + TCAs & $\begin{array}{l}\text { Serotonin syndrome } \\
\text { TCA toxicity }\end{array}$ & $32(8)$ \\
\hline Methotrexate + Omeprazole & $\begin{array}{l}\text { Increased methotrexate } \\
\text { concentration }\end{array}$ & $28(7)$ \\
\hline Ciprofloxacin + Theophylline & $\begin{array}{l}\text { Increased theophylline } \\
\text { toxicity }\end{array}$ & $4(1.0)$ \\
\hline Prednisone + Levofloxacin & $\begin{array}{l}\text { Tendinitis, tendon } \\
\text { rupture }\end{array}$ & $6(1.5)$ \\
\hline $\begin{array}{l}\text { Prochlorperazine + } \\
\text { Escitalopram }\end{array}$ & $\begin{array}{l}\text { Prolongation of the QT } \\
\text { interval }\end{array}$ & $6(1.5)$ \\
\hline Ciprofloxacin + Duloxetine & $\begin{array}{l}\text { Increased duloxetine } \\
\text { toxicity }\end{array}$ & $4(1.0)$ \\
\hline
\end{tabular}

Table-4: Drug Interactions at private hospitals of kharian
\begin{tabular}{|l|l|l|}
\hline Drug interaction & Effect & $\begin{array}{l}\text { Number of } \\
\text { interactions\% }\end{array}$ \\
\hline $\begin{array}{l}\text { Potassium sparing diuretics } \\
+ \text { ACE inhibitor }\end{array}$ & Hyperkalaemia & $80(33)$ \\
\hline Omeprazole + Clopidogrel & $\begin{array}{l}\text { Reduced } \\
\text { cardioprotection }\end{array}$ & $30(12.5)$ \\
\hline Ibuprofen+ Aspirin & $\begin{array}{l}\text { Loss of cardioprotective } \\
\text { and anti platelet effect }\end{array}$ & $24(10)$ \\
\hline Orphenadrine+ Topiramate & Hyperthermia & $14(5.8)$ \\
\hline Tizanidine+ Escitalopram & $\begin{array}{l}\text { Prolongation of the QT } \\
\text { interval }\end{array}$ & $14(5.8)$ \\
\hline Propoxyphene+ Duloxetine & $\begin{array}{l}\text { Additive CNS and/or } \\
\text { respiratory depressant } \\
\text { effects }\end{array}$ & $12(5)$ \\
\hline Lorazepam+ Olanzapine & $\begin{array}{l}\text { Additive CNS and/or } \\
\text { cardiorespiratory, } \\
\text { depressant effects }\end{array}$ & $02(0.8)$ \\
\hline Warfarin + Aspirin & $\begin{array}{l}\text { Increased risk of } \\
\text { bleeding }\end{array}$ & $02(0.8)$ \\
\hline $\begin{array}{l}\text { Aluminum hydroxide + } \\
\text { Sodium citrate }\end{array}$ & $\begin{array}{l}\text { Hyperaluminemia and } \\
\text { encephalopathy }\end{array}$ & $02(0.8)$ \\
\hline
\end{tabular}

Drug interactions at public hospital of Kharian were shown as frequency with percentage was shown in table-2.

In private sector, two major hospitals were selected, Faizan Memorial Hospital Jhelum and Elahi Hospital Jhelum from Jhelum. Prescriptions totaling 400 were checked. Drug interactions details were shown in Table-3. Najam Hospital Kharian and Allama lqbal International Hospital Kharian. 
240 prescriptions from hospitals of Kharian were checked. Drug interactions details depicted in Table-4.

\section{DISCUSSION}

Our study depicts the situation of drug interactions between government run setups and that in private hospitals. In undeveloped countries, like Pakistan, patients receiving healthcare at a hospital are at risk of drug drug interaction and other adverse/ iatrogenic effects. This phenomenon can be explained by a large burden of patients on doctors, absence of follow up visits and no facility to scan drug drug interactions ${ }^{22}$.

Prevalence of drug drug interactions is similar to that when compared with other studies from different countries $(27.9-83.4 \%)^{13-18}$. Our results have led us to believe that public sector hospitals have a higher percentage of drug drug interactions. Public hospitals have $63 \%$ and $93 \%$ interactions in prescriptions in Jhelum and Kharian respectively. DHQ Jhelum showed better performance due to greater number of healthcare workers in its staff compared with Kharian THQ. Among private hospitals, Jhelum showed $20 \%$ drug interactions and Kharian showed $75 \%$ of drug interactions. This could be due to a greater number of staff in private hospitals in Jhelum.

It can be concluded from our study that drug drug interactions are occurring in both private and public hospitals. This problem needs serious addressing. To prevent such occurrence a full faculty of healthcare workers should be present at the hospitals and the work load should be manageable for them. Present study suggested that prescribers' knowledge regarding different significant DDIs is inadequate. Our findings were in line with other researches hence, there is need to develop systems that alert and educate prescribers about significant DDIs.

Limitation: Our study had several limitations like financial constraints, time restrictions, small sample number and fewer resources.

\section{CONCLUSION}

We concluded that frequency of drug interactions were more in public sector hospitals. Hence, a possible reason for such a result could be the greater patient load on public sector hospitals and less number of appointed doctors in such facilities.

Author's contribution: HAM \& MZA: Overall supervision, write up and literature review. AS \&AK: Statistics application analysis literature review, help in write up. HA, AA and TL: Literature review help in write-up.

Acknowledgement: I am thankful to Allah and all my colleagues for their help.

Conflict of Interest: None to declare

Financial Disclosure: None

\section{REFERENCES}

1. Pirmohamed M, James S, Meakin S, Green C, Scott AK, Walley TJ, et al. Adverse drug reactions as cause of admission to hospital: prospective analysis of 18820 patients. BMJ. 2004;329:15-9.
2. Juurlink DN, Mamdani M, Kopp A, Laupacis A, Redelmeier DA. Drugdrug interactions among elderly patients hospitalized for drug toxicity. JAMA. 2003;289:1652-58.

3. Lazarou J, Pomeranz BH, Corey PN. Incidence of adverse drug reactions in hospitalized patients: a meta-analysis of prospective studies. JAMA. 1998;279:1200-5.

4. Tulner LR, Frankfort SV, Gijsen GJ, Van-Campen JP, Koks $\mathrm{CH}$, Beijnen JH. Drug-drug interactions in a geriatric outpatient cohort. Drug \& Aging. 2008; 25:343-55.

5. Magro L, Moretti U, Leone R. Epidemiology and characteristics of adverse drug reactions caused by drug-drug interactions. Expert Opin Drug Saf. 2012;11:83-94.

6. Pedros C, Quintana B, Rebolledo M, Porta N, Vallano A, Arnau JM. Prevalence, risk factors and main features of adverse drug reactions leading to hospital admission. Eur J Clin Pharmacol. 2014; 70:361-7.

7. Ismail M, Iqbal Z, Khattak MB, Khan MI, Arsalan $\mathrm{H}$, Javaid A, et al. Potential drug-drug interactions in internal medicine wards in hospital setting in Pakistan. Int J Clin Pharm. 2013;35:455-62.

8. Carvalho RE, Reis AM, Faria LM, Zago KS, Cassiani SH. Prevalence of drug interactions in

1. intensive care units in Brazil. Acta paul enferm. 2013;26:150-7.

9. Ismail M, Iqbal Z, Khan MI, Javaid A, Arsalan $\mathrm{H}$, Farhadullah $\mathrm{H}$, et al. Frequency, levels and predictors of potential drug-drug interactions in a pediatrics ward of a teaching hospital in Pakistan. Trop J Pharm Res. 2013;12:401-6.

10. Rafi MS, Naqvi SB, Khan MU, Fayyaz M, Ashraf N, Khan MA, et al. Evaluation of potential drug-drug interactions with antidepressants in two tertiary care hospitals. J Clin Diagn Res. 2015;9:FC05-8.

11. Vandael E, Marynissen T, Reyntens J, Spriet I, Vandenberghe J, Willems R, et al. Frequency of use of QT-interval prolonging drugs in psychiatry in Belgium. Int J Clin Pharm. 2014;36:757-65.

12. Van-Leeuwen RW, Brundel DH, Neef $C$, Van-Gelder T, Mathijssen RH, Burger DM, et al. Prevalence of potential drug-drug interactions in cancer patients treated with oral anticancer drugs. $\mathrm{Br} \mathrm{J}$ Cancer. 2013;108:1071-8

13. Chelkeba L, Alemseged F, Bedada W. Assessment of potential drugdrug interactions among outpatients receiving cardiovascular medications at Jimma University specialized hospital, south West Ethiopia. Int J Basic Clin Pharmacol. 2013;2:144-52.

14. Feinstein J, Dai D, Zhong W, Freedman J, Feudtner C. Potential drug-drug interactions in infant, child, and adolescent patients in Children's hospitals. Pediatrics. 2015;135:e99-108.

15. Patel PS, Rana DA, Suthar JV, Malhotra SD, Patel VJ. A study of potential adverse drug-drug

2. interactions among prescribed drugs in medicine outpatient department of a tertiary care teaching

3. hospital. J Basic Clin Pharm. 2014:5:44-8.

16. Chavda NB, Solanky PP, Baria H, Naik R, Bharti K. Study of potential drug-drug interaction between prescribed drugs in patients attending outpatient department of medicine at tertiary-care hospital in South Gujarat region. Natl J Physiol Pharm Pharmacol. 2015;5:236-42.

17. Aparasu R, Baer R, Aparasu A. Clinically important potential drug-drug interactions in outpatient settings. Research in Social and Administrative Pharmacy. 2007;3(4):426-37.

18. Janchawee B, Wongpoowarak W, Owatranporn T, Chongsuvivatwong V. Pharmacoepidemiologic study of potential drug interactions in outpatients of a university hospital in Thailand. J Clin Pharm Ther. 2005;30:13-20.

19. Saeed A, Ibrahim H. Reasons for the problems faced by patients in government hospitals: results of a survey in a government hospital in Karachi, Pakistan. J Pak Med Assoc. 2005;55:45-7.

20. Henriksen K, Battles JB, Keyes MA, Grady ML. Advances in patient safety: new directions and alternative approaches. Agency for Healthcare Research and Quality. Available at: https://www.academia.edu/9612902/Using Patient Complaints to Pr omote_Patient_Safety_Agency_for_Healthcare_Research_and_Qualit y_Advances_in_Patient_Safety_New_Directions_and_Alternative_App roaches Volume 2 2008. Accessed on 20 June 2020.

21. 2016.export.gov. 2021. [online] Available at: <https://2016.export.gov/industry/health/healthcareresourceguide/eg_ main_108609.asp> [Accessed 9 April 2021].

22. Butt HA, Khan A, Suleman N. Occurrence of possible drug related interactions in medical patients in out-patient departments of Pakistan. Int J Basic Clin Pharmacol 2020;9:1503-8. 